\title{
SATIRE IN GREEN: MARKED CLOTHING AND THE TECHNIQUE OF INDIGNATIO AT JUVENAL 5.141-45
}

\author{
Marianne Hopman
}

\begin{abstract}
$\sim$
Abstract. At Juvenal 5.141-45, Virro distributes a curious series of presents to the children of his impoverished client Trebius: a viridis thorax, nuts, and an as. Through an exploration of the connotations attached to these gifts, I argue that the scene provides a vivid mise en abyme for the rest of the poem. Just as the dinner offered to Trebius is not only meager but transforms him into a buffoon, the presents given to his children are both mean and perverse. In particular, the viridis thorax has un-Roman and effeminate connotations akin to the description of patronage as a sexual perversion in Satire 9.
\end{abstract}

FOR MODERN READERS, one of the many challenges raised by Juvenal's Satires has to do with structure and coherence. While we enjoy the vivid and colorful details of the individual scenes brought before our eyes, the logic that connects one vignette to the other sometimes eludes us. Looking for unifying factors or, alternatively, stressing their absence, has therefore been a major focus in the scholarship on Juvenal. This concern is reflected by the care with which almost every recent commentary sketches the composition of each satire.

One way to think about that issue is to keep in mind that an ancient audience may have had criteria of "unity" and "coherence" that are different from ours. However, it may also be that our limited knowledge of the-direct or indirect-referent of the Satires, the reality of Rome, prevents us from appreciating details that subtly connect one scene to another. ${ }^{1}$ Focusing on the viridis thorax and the other presents given by Virro to Trebius' children at S.143-44, this paper explores the significance of these objects in Roman Society as we see it represented in

${ }^{1}$ The larger and complex question of the relation between Juvenal's poetry and the social reality of Rome falls outside the scope of this article. For a stimulating view on how the genre of satire and the persona of the satirist affect the representation of the social reality of patronage in Juvenal, see Cloud 1989. 
literary sources. A more precise understanding of the connotations attached to the gifts helps us understand how the passage, often dismissed by commentators, is in fact fully relevant to the rest of the satire.

Virro's distribution of presents belongs to a climactic moment in the course of the dinner-with separate menus for patron and clientthat he offers to his impoverished dependent Trebius. After a systematic contrast between the meager courses offered to Trebius and the luxurious dinner enjoyed by the patron Virro and his fellow Virrones, the satire reaches a point when Trebius is not offered any food at all and is left watching Virro eat (114-27). As Morford and Braund have both underlined, at this stage the rift between patron and client is complete. ${ }^{2}$ The gap is embodied in lines 127-31 through the example of toasts: never will Virro drink to Trebius' health, nor will any of the clients dare to toast him themselves.

At that moment, the speaker interrupts the menu sequence. In a vehement outburst of indignatio, he picks up the theme (already evoked at the beginning of the satire, lines 12-15) of greed and money as a perversion of amicitia, and he offers a hypothetical picture of what the situation would be if some divine intervention were to raise Trebius' fortune to the equestrian census (132-33): Virro would treat him as an equal, an amicus (134) and a frater (135). In marked contrast to his present meanness and silence, Virro would be eager to talk to Trebius and offer him the choicest foods but only because he would be interested in Trebius' money (136-37). Going one step further (tamen, 137), Virro's greed could even completely reverse the roles: Virro would be transformed into an inheritance-hunter, and Trebius would become Virro's patron (dominus et domini rex,137), provided he made sure to remain childless (137-39). ${ }^{3}$

So far, the train of thought is relatively clear. It is more difficult, however, to understand the next vignette and its relation to the rest of the picture. In lines 141-45, Trebius' wife or concubine Mycale gives birth to triplets; Virro rejoices and distributes gifts—a green tunic, some very small nuts and a coin:

sed tua nunc Mycale pariat licet et pueros tres

in gremium patris fundat semel, ipse loquaci

${ }^{2}$ Morford 1977, 237; Braund 1996, 296.

${ }^{3}$ For the captator as a common target for the satirists, see Hor. Sat. 2.5.31; Juv. 1.3741 and 12.93-130. For a list of passages related to captatio in Roman literature, see Champlin 1991, 201-2. 
gaudebit nido, viridem thoraca iubebit adferri minimasque nuces assemque rogatum, ad mensam quotiens parasitus venerit infans.

The distribution of presents is a puzzle, for indeed this apparent generosity seems to mark a rather abrupt change in Virro's character. Duff calls the lines "strikingly irrelevant," and Courtney finds them "not fully relevant." ${ }^{4}$ Highet suggests that the lines bear the trace of Juvenal's irresistible love for children and that "Juvenal, even at the cost of breaking the consistency of his character-sketch, cannot bear to think of any man's being cruel to a child." ${ }^{5}$ Although this psychologizing explanation is not satisfying, Highet's remark emphasizes the logical problem raised by these lines and their relation to the rest of the satire. The text itself is reasonably sound. To my knowledge, the manuscript tradition offers no variant reading for this particular passage. Even though the possibility of corruption can never be ruled out, it therefore seems better to try first to interpret the text as it is than to resort to emendation. ${ }^{6}$

Various hypotheses have been offered to solve the paradox and explain how Virro's distribution of presents fits into the rest of the satire. Building on the idea that Mycale is the name of a lower-status woman and that the children she bears are illegitimate, older commentators like Friedländer and Wilson thought that lines 141-45 still belong to the hypothesis that Trebius is rich and that Virro is courting him in the hope of an inheritance. ${ }^{7}$ This passage would thus convey a contrast in Virro's

${ }^{4}$ Duff 1898, 198; Courtney 1980, 247.

${ }^{5}$ Highet 1954, 145.

${ }^{6}$ Hendry 1998, 255, has suggested emending line 143 into gaudebis nido, viridem thoraca iubebis. In this reading, Trebius becomes the subject of the sentence and behaves kindly to his own children. Although the emendation solves the problem raised by Virro's change of character, it does not quite fit into the rest of the satire. Hendry's emendation involves understanding ipse in line 142 as a reference to Trebius. However, ipse is markedly used in Satire 5 to refer to Virro (lines 30, 37, 56, 86, 107, 114,142) and to convey sarcastic respect for him. Using ipse with reference to Trebius at line 142 would ruin the effect. Besides, the label parasitus infans (145) loses much of its force if it is the result of Trebius' benevolence toward his own children, while it makes much better sense interpreted as the result of the interaction between Virro and Trebius' offspring. Finally, it seems to me that Hendry's argument is vitiated by his underlying hypothesis that "the scene is clearly Trebius' home, not Virro's" and that "a party such as the one described in this satire ... is no place for children" (254). Satire 1 describes how real or fictitious wives would be used to get more money from the sportula (1.120-26). Producing one's children at a dinner party is in keeping with this idea.

${ }^{7}$ Friedländer 1895, 274; Wilson 1907, 63. 
attitude towards the legitimate and illegitimate children that might be born to a rich Trebius. While Virro would not want Trebius to bear any legitimate offspring (138-40), he would not mind any that were illegitimate and would court Trebius through his children by offering them little presents (141-45). This hypothesis is best refuted by reference to the commentary of Mayor, who argued that the nunc of line 141 has the strong meaning "as it is" and marks a return to the reality of the poem. ${ }^{8}$ This is confirmed by the use of verbal moods in the two vignettes. The subjunctives, which describe the hypothetical situation when Virro is rich (donaret, fieres, uis, luserit), contrast with the indicatives used for the distribution of presents, which belong to the reality of the poem (licet, gaudebit, iubebit). The subjunctives pariat and fundat, which depend on licet, do not mean that a hypothetical situation is described here. Licet should not be taken as the equivalent of $s i$ followed by a hypothetical clause, since we would then expect the subjunctive instead of the indicative future in the main clause. ${ }^{9}$ To understand the sentence better, I suggest breaking it in two, with a full-stop after the emphatic semel: "as it is now, your Mycale might as well give birth and put three children in their father's lap all at one go." The following future clauses are an afterthought indicating Virro's reaction in the reality of the satire: he will rejoice at the chattering nest and will order presents to be delivered.

Lines 135-45 thus build up a contrast between the captator Virro's gift to a hypothetically rich Trebius on the one hand and the "real" Virro's distribution of presents to the three children of poor Trebius on the other. In fact, this contrast between two kinds of presents in two different situations has a parallel in Satire 12, also in a context of legacy hunting, where the existence of three heirs has important consequences too. As the speaker rejoices and dedicates offerings to the gods in his gratitude that Catullus has escaped shipwreck, he emphasizes that his presents have nothing to do with legacy hunting: Catullus has three children, which makes him a sterilis amicus as far as legacy hunting is concerned (12.93-98). The speaker's offerings are then contrasted with the extravagant dedications made by legacy hunters whenever the rich and childless Gallitta or Pacius have a touch of fever (12.98-130). Similarly, Satire 5 contrasts Virro's behavior in two different situations. In the hypothetical picture, his offer of choice food to Trebius belongs to a strategy of legacy hunting. In the reality of the poem, Virro's presents to the children of poor Trebius must have a different purpose.

\footnotetext{
${ }^{8}$ Mayor 1886, 266. For a full exposition of the arguments in favor of Mayor's interpretation, see Duff 1898, 198.

${ }^{9}$ This insight was suggested to me by Professor Jonathan Powell, per litteras.
} 
The idea that the distribution of presents belongs to the reality of the poem is now accepted by most commentators. Its function and integration within the satire, however, have not been satisfactorily understood. The standard explanation is that, in the current situation, Virro can afford to rejoice and be nice to the children because he has no hope of inheriting anything from poor Trebius. The birth of triplets does not cause him any disappointment, and the distribution of presents is thus taken as authentic, albeit cheap beneficence. Its main point would be to act as a foil to Virro's previous anxiety for a hypothetically rich Trebius to remain childless and therefore to emphasize his greed as a legacy hunter as well as his meanness as a patron.

Greed and cheapness are certainly two traits conveyed by the presents, and maybe more so than has so far been acknowledged by commentators. In particular, the distribution of nuts, which are very small (minimae, 144), can be read as a reversal of social habits and literary topoi destined to emphasize the generosity of the donor. It is well attested that nuts were distributed to children to play with and eat in festive contexts, like weddings or birthdays, and it was a common practice for generous masters to give nuts to the children of their dependants. ${ }^{10}$ An anecdote preserved by Stobaeus and attributed by him to Serenus tells how Gellias of Agrigento distributed nuts and figs to the children of his slaves to make a very mean patron ashamed of himself. ${ }^{11}$ At first sight, Virro's distribution seems to fit into this generous pattern, but the epithet minimae immediately undercuts his benevolence. In fact, Pliny points out that walnuts were valued for sparsiones precisely because of their large size. ${ }^{12}$ Giving out some tiny ones, or possibly some hazelnuts, twists the topos and turns a generous sparsio into a meager distribution. A similar depreciation of the as is brought up by its epithet, emphatically positioned at the end of the line: not only is the as the smallest unit of coinage, but it also has to be begged for, rogatum (144). While it does not seem to have been as usual to distribute coins to children as to give them nuts, I suggest that this present can be read as a caricature of the sportula. In Satire 1, the speaker emphasizes the patron's fear of being cheated by his clients and the strict accounting involved in the distribution of the sportula (1.97-99). This climate of suspicion and meanness is pushed one step further here where the humiliation of the baby client results in the

${ }^{10}$ For nuts given out at a wedding, see, e.g., Catullus 61.126-35. For nuts on birthdays, see, among others, CIL 10.5849, where a rich citizen grants money so that a sportula can be distributed to the people and nuces given to the children on his birthday.

${ }^{11}$ Stob. 4.430.18 Hense.

${ }^{12}$ Plin. Nat. 15.24. 
smallest possible monetary gift. Both the minimae nuces and the as rogatum, then, distort and caricature gifts distributed in a patronage context. The chiasmus that frames the two nouns between two derogatory epithets stresses the parallelism of the two presents in structure and significance. Similarly, the epithet viridis, which qualifies the thorax, may also be an indication of Virro's meanness.

Current attempts to explain the color of the thorax take it as a reference to the most popular chariot team, the factio prasina. Granted, there is evidence for Juvenal using the adjective viridis as synonym of prasinus in the context of chariot teams, ${ }^{13}$ and one of Martial's apophoreta also confirms that people would wear clothes of the color of their favorite team. ${ }^{14}$ However, this interpretation is very much at odds with the deprecating tone of the other epithets. Indeed, the green faction is always presented in a positive light in contemporary literature. A garment of the color of the winning team would probably have been considered a very exciting present, and this does not match the insignificance of the two other gifts.

To my knowledge, the only attempt to read the epithet viridis as a deprecating qualifier was made by Ullman. ${ }^{15}$ In his interpretation, the thorax is taken as a metallic breastplate. Accordingly, its green color is interpreted as verdigris and seen as a mark of age and bad condition. However, although it is true that the word thorax often refers to a piece of metal armor, it seems unlikely that it should thus be interpreted here. This would require us to assume, as Ullman does, that children were given toy uniforms made of metal and that Virro would have old ones to give away. None of these hypotheses relies on good evidence.

Rather than a piece of a metal armor, it makes better sense, I think, to interpret the thorax given by Virro as a textile. We do indeed have instances, both in Greek and in Latin, where the word thorax clearly refers to a cloth garment. $\lambda \iota^{\prime}{ }_{0} \theta \omega \dot{\rho} \eta \xi$, "wearing a linen tunic," is a standard epithet for Homeric warriors, and linen thoraces are mentioned in Alcaeus, Herodotus, and Pausanias. ${ }^{16}$ In a fragment of Lucilius, toracia are mentioned among female apparel made of fabric. ${ }^{17}$ In Suetonius,

${ }^{13}$ Juv. 11.197-98: "totam hodie Romam circus capit, et fragor aurem / percutit, eventum viridis quo colligo panni."

${ }^{14}$ Mart. 14.131: "Si veneto prasinove faves, qui coccina sumis / ne fias ista transfuga sorte vide." On this epigram, see Leary 1996, 195-96.

${ }^{15}$ Ullman 1966, 281.

${ }^{16}$ Hom. Il. 2.529 and 830; Alc. 357.6 Lobel-Page; Hdt. 2.182 and 3.47; Paus. 6.19.7.

${ }^{17}$ Lucil. 2.71 Marx = 2.13 Charpin, preserved by Non. 539.24. 
Augustus wears a woolen thorax to protect himself against the winter cold. ${ }^{18}$ Although this meaning of thorax is certainly not the more common one in Latin, it seems more reasonable and realistic that the thorax offered by Virro to a child be an item of clothing rather than a piece of metal armor.

If the thorax is made of cloth, then its green color has to be interpreted in terms of dye. In fact, as Blümner pointed out, viridis is a highly unusual color for a Roman garment. ${ }^{19}$ In a society where dyes and hues carried precise connotations and social significance, the rare color of the thorax would thus have been immediately noticed and interpreted. ${ }^{20}$ Viridis is not even mentioned in a memorable passage of the Ars Amatoria, where Ovid lists no fewer than ten colors of dye aside from purple and recommends that women match the color of their clothing to their complexion..$^{21}$ To my knowledge, the only mention of viridis in the context of a dye has to do with an intermediate step in the process of manufacturing the double-dyed Tyrian purple, which was highly prized. According to Pliny's description of that process, the wool was first soaked in a bath produced by the Murex pelagium, which dyed the wool green (viridis). The wool was then immersed in a vat from another kind of gastropod, the Murex bucinum. The overlay of purple on green produced the gleaming and brilliant scarlet that Pliny likens to congealed blood and that was the hallmark of double-dyed Tyrian purple..$^{22}$ In that context, the viridis color of the thorax may indicate that it has been through only half the process. Instead of coming out in a gleaming Tyrian dye, the thorax remains pale green. Just as the nuces are small and the as has to be begged for, a potentially beautiful garment turns out to be of mediocre quality and emphasizes Virro's meanness. The presents given to the child thus mirror the dinner offered to the father and illustrate the idea, extensively developed in Satire 14, that children resemble and ape their parents. In fact, the parallel between father and progeny as recipients of Virro's gifts is emphasized here by the shift of number from triplets

${ }^{18}$ Suet. Aug. 82.1.

${ }^{19}$ Blümner 1892, 215: "Von grüngefärbten Geweben ist nicht haüfig die Rede."

${ }^{20}$ On the variety of dyes and their social significance, see Daremberg-Saglio s.v. purpura (Besnier) and Sebesta 1994. Plin. HN 9.136-37 provides a very informative list of the various dyes, the way they are made, and how they come in and out of fashion.

${ }^{21}$ Ov. Ars 3.169-92.

${ }^{22}$ Plin. $H N$ 9.135. For a detailed reading of this passage, see Sebesta 1994, 69. For a technical study of green dye in Antiquity and how it was obtained by interrupting the photochemical development of purple, see Dedekind 1898. 
(pueri tres, 141) to a single child (parasitus infans, 145). Just as the longawaited cena turns out to be a meager dinner, at least for the poor client, the gifts that the child pleads for turn out to be disappointing.

The context of the distribution, however, suggests that there is more than only meanness in the presents given out by Virro. Just as the double-menu dinner offered to the father is not only meager but intentionally transforms him into a buffoon (156-60), the gifts offered to the child are not only mean but, as Barr, Jenkyns, and Tennant have suggested, contribute to the corruption of the child and to his transformation into a parasite, as it is evoked in the rest of the vignette. ${ }^{23}$ In a masterpiece of compression and a splendid escalation of imagination, we see the children passing from the stage of new-born babies (141-42), to chattering infants (142-43), to older children able to play with nuts and ask for presents (rogatum, 144). Each stage adds a new element of degradation on Virro's part until the climactic transformation of the child into a parasitus infans (145).

The vignette starts with a contrast between Virro's eagerness for a hypothetically rich Trebius to remain childless and his indifference to the birth of one (141) or even three heirs (142) to Trebius in reality. Raising triplets may represent a heavy burden for the impoverished client, but this is not Virro's concern. In fact, his indifference to the matter is followed by an apparent display of interest (gaudebit, 143). In the context of Satire 5, however, the term gaudebit has an ambiguous flavor, since it calls to mind the cynical and perverse pleasure Virro takes in the comoedia, the mimus offered by his humiliated client Trebius (157-58). Like his father, the child is transformed into a buffoon, a scurra who offers an entertaining spectacle to his patron. ${ }^{24}$ In fact, Virro's rejoicing about the children's birth is followed by a rapid degradation of their status. The comparison with a loquax nidus has an ambiguous flavor, between tender and derogatory, since it alludes to Virgil's simile of a swallow that flies around a great man's house to find some food for her babies, pabula parva legens nidisque loquacibus escas (Aen. 12.475). The Virgilian tone here both echoes, and strongly contrasts with, the Virgilian allusion to a parvulus Aeneas (Aen. 4.328-29) in the hypothetical situation a few lines earlier where Trebius is envisaged as a rich man (138-39). While the former dignifies Trebius's hypothetical offspring by comparing

\footnotetext{
${ }^{23}$ Rudd and Barr 1991, 168; Jenkyns 1982, 195-96; Tennant 1993.

${ }^{24}$ About the scurra as the flip side of the cliens in Horace, and for an analysis of the transformation of Trebius into a scurra, see Morford 1977, 226-28.
} 
him to the potential son of Dido and Aeneas, the latter implicitly compares his children to animals, whereas Virro is the equivalent of Virgil's rich man. The social distance is then reinforced by the touch of authority conveyed by the expression iubebit adferri, which recalls the formulaic fieri iussit used on imperial dedications. ${ }^{25}$ The distribution of presents brings us to the climax of the vignette, the transformation of the baby client into a baby parasite, parasitus infans (145), who, as Damon has shown, is the negative image of the cliens. ${ }^{26}$ Virro's distribution of presents is therefore part of a degrading process whereby Trebius and his children are transformed into the flip side of the Roman client, the parasite. The viridis thorax marks an important step in the process and is a perverse gift that endows the child with un-Roman and feminizing characteristics.

The idea that the viridis thorax is a perverse gift has already been suggested by the scholiast, who glossed it armilausiam prasinam, ut simiae. ${ }^{27}$ In his view, then, the viridis thorax would transform the child into a monkey, possibly so that he can participate in the entertaining comedy that Trebius involuntarily offers his patron (157-58). The problem with this interpretation, however, is that there is no evidence that a green tunic would be characteristic of a monkey. The evidence collected by McDermott demonstrates that apes could be used as pets and dressed in all sorts of costumes. ${ }^{28}$ No single garment, therefore, can metonymically stand for an ape.

The reliability of the scholiast's gloss therefore appears to be questionable, as often in the scholia to Juvenal. ${ }^{29}$ In fact, this gloss looks like a translation of the viridis thorax, with armilausia corresponding to thorax and prasina to viridis. The additional reference to an ape is likely to be contamination from a later passage in the satire, which evokes an ape dressed like a soldier (qui tegitur parma et galea), riding a goat and throwing a javelin (154-55). Not knowing what the viridis thorax really refers to, the scholiast associated it with another reference to military equipment in the poem and thought it was part of an ape's paraphernalia, just like the helmet and the shield mentioned a few lines afterward. The absence of direct connections between the viridis thorax and an ape also rules out the interpretation of Rose, who relies heavily on the

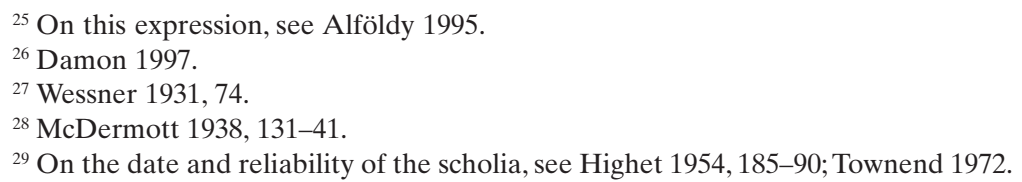


scholiast in suggesting that the viridis thorax is a metonym for a monkey that is offered to the child and trained to ask for the very small nuts and the as. $^{30}$

In spite of its limitations, however, the scholion is interesting because it seems to emphasize the foreign connotations of the word thorax as a piece of clothing. The gloss armilausia is apparently a foreign word, possibly of German origin. ${ }^{31}$ These foreign connotations parallel the Greek atmosphere conveyed by the word thorax, which, as noted above, is rarely used in Latin to designate a piece of clothing. In this sense, therefore, the word thorax is not fully assimilated into Latin and retains its Greek connotations.

In the context of the Satires, these connotations take on a precise meaning with regard to the strong xenophobia of Juvenal's persona (or personae) and his view of the role of the Greeks in the decline of patronage. In Satire 3, Umbricius accuses the Greek newcomers of supplanting the old Roman clientes (3.58-125) and depicts their servility with both scorn and envy. As Damon has shown, the type of the parasitus is used by Umbricius as a way to characterize the incoming Greeks and contrast them with Roman clients. ${ }^{32}$ In Satire 3, therefore, Greek and parasite almost stand as synonyms. In Satire 5, Trebius, although a Roman citizen who can boast the tria nomina (127), accepts a position that is unworthy of a Roman (163-65) and becomes a parasitus as servile as the Greeks of Satire 3, albeit less successful than they. The Greek thorax (143), together with Mycale's Greek name (141), contribute to Trebius' decline from Roman cliens into Greek parasitus. The process is fulfilled through the expression parasitus infans, applied to his child at the end of the vignette.

Moreover, the thorax seems to bear other connotations that make it a garment which is not only foreign but also effeminate. As noted above, it is difficult to have a precise idea of what it actually was, since

${ }^{30}$ Rose 1938, 12-13. There are many problems in Rose's interpretation. From a grammatical point of view, he thinks that the three accusatives are not on the same level and takes only viridem thoraca as the subject of adferri, while minimasque nuces assemque would be the object of rogatum, which he takes as a supine. As Rose himself points out, however, this construction does not match Juvenal's use of the double -que.

${ }^{31}$ See $T L L$ ii $614.65-75$ s.v. armilausa et armilausia (Bögel): "germanicam originem habere videtur, seu tractum est a nomine populi Armalausorum vel Armilausinorum seu populus a veste nomen accepit." Isidorus gives an etymologizing explanation that is interesting as far as the description of the shape of the armilausia is concerned but is not a reliable etymology of the word: "armilausa vulgo vocata, quod ante et retro divisa atque aperta est, in armos tantum clausa, quasi 'armiclausa' C littera ablata” (Orig. 19.22.28).

${ }^{32}$ Damon 1997, 174-81. 
Lucilius and Suetonius are the only other Latin authors who use the word to designate a piece of clothing. However, their references suggest that it was quite unusual for a Roman male to wear a thorax. In Suetonius, it is one of numerous garments worn by Augustus in winter to protect his feeble constitution: "hieme quaternis cum pingui toga tunicis et subucula $\mathrm{e}<\mathrm{t}>$ thorace laneo et feminalibus et tibialibus muniebatur." ${ }^{33}$ In his commentary, Shuckburgh points out that the feminales and the tibiales are woolen wrappers (fasciae) generally worn only by invalids. ${ }^{34}$ Suetonius does not pass any overt judgment on Augustus' physical weakness, but it certainly contrasts with the often-praised manly capacity for enduring heat and cold that is evoked, for instance, in Sallust's portrayal of Catiline. ${ }^{35}$ In this passage, then, wearing a thorax is a mask of feebleness and defective health, which contrasts with the Roman ideal of males endowed with a strong constitution. The suggested lack of manliness ties in with Suetonius' earlier mention of rumors accusing Augustus of effeminacy and with his report that a dramatic line mentioning a cinaedus who ruled the world with only one finger was interpreted by the Roman crowd as a reference to Augustus. ${ }^{36}$

The unmanly connotations carried by the thorax in the Suetonius passage are confirmed in the Lucilius fragment, where it is part of a list of garments: $\left\langle c>h<i>\right.$ rodyt $<o e>$ aurati, $<r>i c a<e>$, toracia, mitrae. ${ }^{37}$ Since this is a fragment preserved by Nonius Marcellus, we know very little about its context except that it comes from the second book of Lucilius' Satires, which describes the suit brought by Albucius against Q. Mucius Scaevola. On Charpin's interpretation, the list is part of Albucius' accusation, which charged Scaevola with wearing or stealing these clothes. ${ }^{38}$ In spite of these uncertainties, it is quite clear that the toracia are listed among female garments. We know from Gellius that the chirodyti are long tunics that cover the arms as far as the wrists and that, according to Roman standards, should be worn only by women. ${ }^{39}$ Varro defines the

${ }^{33}$ Suet. Aug. 82.1.

${ }^{34}$ Shuckburgh 1896, 148. For fasciae worn by invalids, see Hor. Sat. 2.3.254, Quint. 11.3.144. Shackleton Bailey stresses that in Cic. $A H$ 2.3, the fasciae worn by Pompey, probably for health reasons, are gibed at as a foppish affectation.

${ }^{35}$ Sall. Cat. 5.1-3.

${ }^{36}$ Suet. Aug. 68.

${ }^{37}$ Lucil. 2.71 Marx = 2.13 Charpin, preserved by Non. 539.24 .

${ }^{38}$ Charpin 1978, 218-19.

${ }^{39}$ Gell. 6.12.1-3: "tunicis uti virum prolixis ultra brachia et usque in primores manus ac prope in digitos Romae atque in omni Latio indecorum fuit. eas tunicas Graeco vocabulo nostri 'chirodytas' appellauerunt feminisque solis vestem longe lateque diffusam decere existimaverunt ad ulnas cruraque adversus oculos protegenda." 
rica as a headdress worn by women when they perform sacrifices, ${ }^{40}$ and Novius Paedio mentions it in a list of female attire. ${ }^{41}$ Finally, the mitra is an oriental headdress fastened under the chin and used by women to hold their hair. It is worn, for instance, by Ariadne in Catullus 64.42

Being strongly marked as female clothes, the chirodyti, the rica, and the mitra are also used to characterize masculine behaviors that blur traditional gender boundaries. According to Gellius, when Euclides came disguised as a woman to visit Socrates in defiance of the interdiction prohibiting the citizens of Megara from entering Athens, he wore a long tunic (tunica longa), a multi-colored mantle (pallium versicolor), and a rica covering his head. ${ }^{43}$ Similarly, a mitra was part of Clodius' attire when he secretly attended the celebration of the Bona Dea. ${ }^{44}$ These clothes are often interpreted-and usually condemned - as signs of effeminacy. A chirodyta tunica is one of the items that Publius Africanus Scipio points out in his criticism of Publius Sulpicius Gallus, whom he calls an effeminate man (homo delicatus) and compares to a cinaedus. ${ }^{45}$ In the Aeneid, Iarbas compares Aeneas to Paris and makes a scornful reference to his train of eunuchs (semivir comitatus), his Maeonian mitra, and his perfumed locks. ${ }^{46}$ It therefore appears that Lucilius' fragment mentions the toracia among female clothes that are markers of effeminacy when worn by men. It is quite possible, then, that the thorax possesses similar connotations and that Virro's present is aimed at transforming Trebius' child into an effeminate individual.

This idea is corroborated by the fact that similarly effeminate con-

${ }^{40}$ Varro LL 5.130.2: "sic rica ab ritu, quod Romano ritu sacrificium feminae cum faciunt, capita velant. mitra et reliqua fere in capite postea addita cum vocabulis graecis." See also Paul. Fest. 288 M.

${ }^{41}$ Novius 71 ap. Non. 539M: molucinam, crocotam, ciridotam, ricam, ricinum.

${ }^{42}$ Cat. 64.63 and 68.

${ }^{43}$ Gell. 7.10.4: "Tum Euclides, qui indidem Megaris erat quique ante id decretum et esse Athenis et audire Socratem consueverat, postquam id decretum sanxerunt, sub noctem, cum advesperasceret, tunica longa muliebri indutus et pallio versicolore amictus et caput rica velatus e domo sua Megaris Athenas ad Socratem commeabat."

${ }^{44}$ Cic. Har. 44.

${ }^{45}$ Gell. 6.12.5: "Verba sunt haec Scipionis: 'Nam qui cotidie unguentatus adversum speculum ornetur, cuius supercilia radantur, qui barba vulsa feminibusque subvulsis ambulet, qui in conuiuiis adulescentulus cum amatore cum chirodyta tunica interior accubuerit, qui non modo vinosus, sed virosus quoque sit, eumne quisquam dubitet, quin idem fecerit, quod cinaedi facere solent?'”

${ }^{46}$ Verg. Aen. 4.215-17: "et nunc ille Paris cum semiviro comitatu, / Maeonia mentum mitra crinemque madentem / subnexus, rapto potitur." See also Aen. 9.616. On the mitra as a garment worn by effeminate men, see Williams 1999, 129 . 
notations are attached in our sources to the color of the thorax, strikingly depicted as green (viridis). I have offered above a first interpretation of that rare color and suggested that it could be read as a mark of Virro's meanness. In the context of Juvenal's Satires, however, this first set of connotations is completed by a second one, which has to do with effeminacy. In other instances where Juvenal uses the adjective viridis, it qualifies plants, herbs, or trees $(3.19,6.228,7.118,14.147)$; emeralds (6.458); the green faction (11.198); and the sunshade (umbella) offered in 9.50 by Naevolus to the cinaedus he serves as a client. ${ }^{47}$

In the context of Satire 9, the reasons why the umbella is viridis are clear. Viridis is the general term for green, whether light (galbinus) or dark (prasinus) ${ }^{48}$ and green is a marker of bad taste and sexual deviance when worn by men. ${ }^{49}$ A transvestite in Satire 2 is caerulea indutus scutulata aut galbina rasa (2.97). Martial 3.82 depicts a fellator dressed in yellowgreen (galbinatus), and next to him a slave who ventilates him with a dark-green fan (prasinum flabellum). Martial 1.96.8-9 uses metaphors of garment colors to denounce those who, like the hypocrites of Juvenal 2, have a strict appearance but behave less honorably, habeat et licet semper / fuscos colores, galbinos habet mores. In Satire 9, the viridis umbella clearly bears similar connotations. In fact, it belongs to a vignette that describes the cinaedus Virro surrounded by objects that are markers of effeminacy: ${ }^{50}$ the cathedra on which he reclines is a seat usually associated with women; ${ }^{51}$ the balls of amber (sucina) that he receives as a present were carried by Roman ladies because of their nice smell $; 52$ and, last but not least, the occasion on which he gets this gift is the Matronalia

${ }^{47}$ It is not easy to identify $t u$ and vos in Naevolus' speech and thus to distinguish who is the donor and who is the recipient of the gifts of 9.50-53. Some critics, including Gérard 1976, 170, understand that Naevolus wishes those presents to be given to him. However, I think that Ferguson 1979, 250, is right to stress that $t u$ in lines $50-53$ has to be Naevolus speaking to himself, which makes the patron the recipient of the gifts. This interpretation fits the economy of gift exchanges that we see attested in Martial 4.88, where the client gives a small gift (parvum munus) to his patron and expects larger ones (dona) in return. Similarly, here, Naevolus gives small presents to his patron (50-53) but is frustrated in his hope of receiving part of his estate in return (54-58).

${ }^{48}$ For a study of the meanings of viridis, its synonyms, and antonyms, see André 1949, 184-87.

${ }^{49}$ On colorful clothing and other markers of effeminacy, see Williams 1999, 129.

${ }^{50}$ See Courtney 1980, 432-33, and Ferguson 1979, 250.

${ }^{51}$ Cf. Juv. 6.91 molles . . . cathedras; Mart.3.63.7 femineas . . cathedras. For further references, see $T L L$ iii 612.9-65 s.v. cathedra (Hoppe), with the gloss: "sella delicatior, qua imprimis utebantur mulieres, apud posteriores etiam sedile quodvis."

${ }^{52}$ Cf., for instance, Ov. Met. 2.365; Prop. 2.24.12; Mart. 3.65.5. 
(femineis kalendis 9.53). The viridis umbella that he receives together with the sucina is clearly designed to fit into the series and to contribute to his characterization as a passive homosexual. It could therefore well be that the viridis thorax of 5.143 carries the same connotations as the viridis umbella of 9.50. This idea is supported by the fact that both the viridis thorax and the viridis umbella are gifts exchanged between patron and client and that in both instances this patron is named Virro. ${ }^{53}$ The question, then, is whether the Virros of Satire 5 and Satire 9 refer to each other.

We do not have much information about the way Juvenal's Satires were published. In particular, we do not know whether they originally appeared as a collection, which would have encouraged the reader to make connections between satires and books. Still, there are clear instances where a character from one satire reappears in another. At the beginning of Satire 4, Crispinus is introduced with reference to his previous appearance in Satire 1: ecce iterum Crispinus at 4.1 harks back to the earlier mention of him at $1.26-69 .{ }^{54}$ We also have characters who circulate from one book of the Satires to another. Gracchus, a member of the Roman elite who takes the role of a bride and marries another man in 2.117-48, reappears as a gladiator in 8.199-210, where his gladiatorial activities, briefly mentioned in $2.143-48$, get fully developed. The two passages feature similar descriptions of Gracchus' flight through the arena (2.144 and 8.206), which shows that Satire 8 refers to the same character as Satire 2. In the light of these examples, it seems quite possible that the Virro of Satire 5 and the Virro of Satire 9 refer to each other, especially since it is a rare name. ${ }^{55}$

${ }^{53}$ Virro is named seven times in Satire $5(39,99,128,134,149$ twice, 156) and once in Satire 9 (35). Most commentators identify the Virro mentioned at 9.35 with Naevolus' patron, but Courtney 1980, 424, stresses that he is not explicitly said to be so and thus takes the mention of his name at 9.35 as a generic example of lust. However, the line is soon followed by a scene of accounting (9.39-42) that clearly and vividly refers to Naevolus' patron. It therefore seems easier to me to understand that the speaker we hear talking in line 39 is the Virro characterized as a cinaedus at 35-37. If we follow Courtney's interpretation, the Virro of 9.35 is not the recipient of the viridis umbella of 9.50, but the key elements for my argument, the fact that Virro is a cinaedus in Satire 9 and that the viridis umbella is an effeminate present, remain valid.

${ }^{54}$ As Braund 1996, 236, points out, the relationship is even more complex, since the beginning of Sat. 4 refers not only to Sat. 1.26-29 but also to Horace Sat. 1.4.13-14: ecce, I Crispinus, where Horace's Crispinus too is making a reappearance from an earlier satire (Sat. 1.1.120).

${ }^{55}$ According to Ferguson 1987, 244, the name is provincial and from Juvenal's district. It is known from Vibidius Virro of the time of Augustus, who was expelled from the 
This hypothesis of a relation between the two Virros is supported by close thematic links that connect Satire 5 and Satire 9 . Both deal with the perversion of patronage, and both are a double-edged attack on both patron and client. As Ferguson, Braund, and others have shown, Satire 5 does not only criticize Virro for serving a double-menu dinner. ${ }^{56}$ It is also framed by the speaker's criticism of Trebius and of his willingness to subject himself to humiliations that place him in the position of a hired buffoon $(5.3-4,171-72)$ or a slave (5.161-65, 172-73). Similarly in Satire 9, as Courtney has argued, the speaker first seems to sympathize with Naevolus' decrepitude, but his apparent compassion soon turns out to be ironical, as the nature of Naevolus' skills is gradually revealed. ${ }^{57}$ The colder, more cynical tone of Satire 9 is certainly very different from the indignatio of Satire 5, but the satiric technique is similar.

Both satires denounce the transformation of patronage into a mercenary relationship, and features suggested in Satire 5 get more fully developed in Satire 9. In Satire 5, the dinner party is cast as the full payment for Trebius' past services, merces solida veterum officiorum (5.13), and it springs from Virro's careful calculation of what he owes to his client (imputat, 5.14 and 5.15). The accounting scene hinted at in Satire 5 through the term imputat is fully developed in Satire 9, where Virro makes a reckoning (computat, 9.40) and has his slaves bring in the reckoning board, count out five thousand sesterces to Naevolus, and enumerate his services (9.39-42). Moreover, both satires pick up the question of children and of the privileges of fatherhood. In the hypothetical picture of 5.132-39, rich Trebius should be careful not to have any children so that Virro can inherit from him. Going one step further, the Naevolus of Satire 9 makes his patron a father so that Virro can now be entered as an heir and receive inheritances in full (9.87-88). More privileges may be added if Naevolus brings the number of his patron's children to three, thus securing him the ius trium liberorum..$^{5}$ Satire 9 thus represents the logical conclusion of the process already at work in Satire 5 or, as Damon puts it, a "reductio ad adsurdum beginning where Satire 5 left off." ${ }^{59}$

Senate for immoral behavior in 17 C.E. (Tac. Ann. 2.48.3), Sex. Vibidius Virro, father of a Vestal Virgin (IG II/III 3532 and 4161), and Sex. Virro of the tribe Sergia, known to be alive in 9 в.C.E. (Front. Aq. 129). Ferguson stresses that all three may, but need not, be the same. For more on Sex. Vibidius Virro, see Syme 1970, 76.

${ }^{56}$ Braund 1996, 308; Ferguson 1979, 185.

${ }^{57}$ Courtney 1980, 425.

${ }^{58}$ On the ius trium liberorum and its privileges, see $R E$ s.v. ius liberorum (Steinwenter).

${ }^{59}$ Damon 1997, 187. 
In the light of those tight connections between Satires 5 and 9, it seems likely that the two Virros refer to each other and are embodiments of a single satiric type, that of the rich patron who is both greedy and deviates from Roman norms of sexuality. In fact, as Robinson has suggested, his very name may be read as a pun on Virro/vir/viridis, ironically emphasizing his lack of virility. ${ }^{60}$ Since the name, rare and provincial, is attested in Juvenal's district, Ferguson has suggested that it may refer to a real individual. ${ }^{61}$ If so, the effeminacy emphasized in Satire 9 would have characterized the real Virro, which makes it likely that it may already be hinted at in Satire 5. But we do not need a figure from real life to connect the Virros from Satires 5 and 9. Greediness, perversity, and sexual deviance are all ingredients that, put together, make up the type of the rich patron. Martial 3.82 provides an interesting illustration of that combination. Here, Zoilus not only offers a double-menu dinner to his clients (22-28) but he is also a fellator (fellat 33). Zoilus coordinates, as it were, the Virros of Satires 5 and 9 and he shows that the double-menu dinner of Satire 5 and the transformation of patronage into a perverted sexual relationship in Satire 9 are part of a coherent whole. Damon has convincingly shown that the transformation of the parasite into a gigolo represents the logical conclusion of the process already at work in Satire $5{ }^{62}$ If so, it could well be that the sexual perversion fully developed in Satire 9 may already be hinted at in Satire 5 through the distribution of an un-Roman, effeminate viridis thorax.

The exploration of the connotations attached to Virro's gifts thus shows how the compressed vignette about Trebius' children relates to the rest of the satire by mirroring it and taking it one step further. The dinner party offered to Trebius can be read as a perversion of the traditional cena supposed to bring together patron and client. Similarly, Virro's treatment of the children distorts topoi about benevolent masters who enjoy the company of the children of their dependants at dinner. ${ }^{63}$ Just as the double-menu dinner is not only a mark of meanness but also aims to transform Trebius into a buffoon, a scurra, the presents given to his child are not only meager, but also perverse. In particular, the viridis thorax seems to be perceived as a highly marked garment with Greek and effeminate connotations, which endows the child with un-Roman, femi-

\footnotetext{
${ }^{60}$ Robinson 1983, 209.

${ }^{61}$ Ferguson 1987, 244.

${ }^{62}$ Damon 1997, 187.

${ }^{63}$ Stories of that sort are told about Archytas of Tarentum in Aelian $V H$ 12.15.12-16 and Gellias of Agrigento in Stobaeus 4.430.18.
} 
nizing characteristics. The gift process thus fulfills Trebius' transformation from a Roman client into a Greek parasite and announces the next step of the degradation, the transformation of patronage into a perverted sexual relationship. Satire 5 hints, in a highly compressed way, at a feature that becomes fully developed in Satire $9 .{ }^{64}$

HARVARd UNIVERSITY

e-mail: hopman@fas.harvard.edu

\section{BIBLIOGRAPHY}

Alföldy, Géza. 1995. "Eine Bauinschrift aus dem Colosseum.” ZPE 109:195-226. André, Jacques. 1949. Étude sur les termes de couleur dans la langue latine. Paris: Klincksieck.

Blümner, Hugo. 1892. "Die Farbenbezeichnungen bei den römischen Dichtern." Berliner Studien 12 (3):1-231.

Braund, Susanna. 1996. Juvenal: Satires, Book 1. Cambridge: Cambridge University Press.

Champlin, Edward. 1991. Final Judgements: Duty and Emotion in Roman Wills, 200 B.C. - A.D. 250. Berkeley and Los Angeles: University of California Press.

Charpin, François. 1978. Lucilius: Satires. Paris: Belles-Lettres.

Cloud, Duncan. 1989. "The Client-Patron Relationship: Emblem and Reality in Juvenal's First Book." In Patronage in Ancient Society, ed. Andrew WallaceHadrill, 205-18. London: Routledge.

Courtney, Edward. 1980. A Commentary on the Satires of Juvenal. London: Athlone Press.

Damon, Cynthia. 1997. The Mask of the Parasite: A Pathology of Roman Patronage. Ann Arbor: University of Michigan Press.

Dedekind, A. 1898. "La pourpre verte et sa valeur pour l'interprétation des écrits des anciens." Archives de zoologie expérimentale 3 (6):467-80.

Duff, James. 1898. D. Iunii Iuvenalis Saturae XIV. Cambridge: Cambridge University Press.

Ferguson, John. 1979. Juvenal: The Satires. New York: St. Martin's Press. -1987. A Prosopography to the Poems of Juvenal. Collection Latomus 200. Brussels: Latomus.

Friedländer, Ludwig. 1895. D. Junii Juvenalis Saturarum Libri V. Leipzig: Hirzel.

${ }^{64}$ I would like to thank Professor Barbara Gold, an anonymous reader for the journal, and Professor Jonathan Powell for many stimulating comments. I am most grateful to Professor Kathleen Coleman for her support and invaluable advice. Any remaining flaws or errors are, of course, my responsibility alone. 
Gérard, Jean. 1976. Juvénal et la réalité contemporaine. Paris: Belles-Lettres. Hendry, Michael. 1998. "Three Cruces in Juvenal.” CQ 48:252-61. Highet, Gilbert. 1954. Juvenal the Satirist. Oxford: Clarendon Press. Jenkyns, Richard. 1982. Three Classical Poets: Sappho, Catullus, and Juvenal. Cambridge, Mass.: Harvard University Press.

Leary, Timothy. 1996. Martial Book XIV: The Apophoreta. London: Duckworth. Mayor, John. 1886. Thirteen Satires of Juvenal. 4th ed. London: Macmillan.

McDermott, William. 1938. The Ape in Antiquity. Baltimore: The Johns Hopkins Press.

Morford, Mark. 1977. “Juvenal's Fifth Satire.” AJP 98:219-45.

Robinson, Steven. 1983. Juvenal: Sixteen Satires upon the Ancient Harlot. Manchester: Carcanet New Press.

Rose, Herbert J. 1938. "Some Passages of Latin Poets.” HSCP 47:1-15.

Rudd, Niall, and William Barr. 1991. Juvenal: The Satires. Oxford: Clarendon Press.

Sebesta, Judith Lynn. 1994. "Tunica Ralla, Tunica Spissa: The Colors and Textiles of Roman Costume." In The World of Roman Costume, ed. Judith Lynn Sebesta and Larissa Bonfante, 65-76. Madison: University of Wisconsin Press.

Shuckburgh, Evelyn. 1896. C. Suetoni Tranquilli Divus Augustus. Cambridge: Cambridge University Press.

Syme, Ronald. 1970. Ten Studies in Tacitus. Oxford: Clarendon Press.

Tennant, P. M. W. 1993. "[Uncle] Virro and Trebius' Offspring: The Relevance of Juvenal Satires 5, Lines 141-45." AClass 36:83-89.

Townend, G. B. 1972. "The Earliest Scholia on Juvenal." CQ 22(n.s.):376-87.

Ullman, Berthold L. 1966. "Miscellanous Comments on Juvenal." In The Classical Tradition: Literary and Historical Studies in Honor of Harry Caplan, ed. Luitpold Wallach, 274-84. Ithaca, N.Y.: Cornell University Press.

Wessner, Paul, ed. 1931. Scholia in Juvenalem vetustiora. Stuttgart: Teubner.

Williams, Craig A. 1999. Roman Homosexuality: Ideologies of Masculinity in Classical Antiquity. Oxford: Oxford University Press.

Wilson, Harry. 1907. D. Ivni Ivvenalis Satvrarvm libri V. New York: University Publishing Company. 